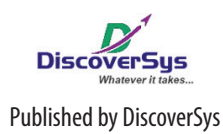

Published by DiscoverSys

\section{The association between hypertension self-management and stroke event in male patients at the Badung District Hospital, Bali}

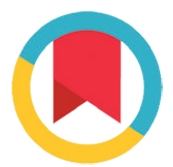

CrossMark

\author{
Ni Kadek Sutini, ${ }^{1 *}$ Ni Wayan Septarini, ${ }^{2}$ I Made Ady Wirawan, ${ }^{2}$ Anak Agung Sagung Sawitri ${ }^{2}$
}

\section{ABSTRACT}

Background and purpose: Hypertension is a major risk factor for stroke. Despite efforts to control hypertension with pharmacological and non-pharmacological therapies, the prevalence of and death from stroke is reported to be increasing. This study aims to determine the association of hypertension self-management with the incidence of stroke in patients with hypertension.

Methods: A case-control study was conducted involving 44 patients suffering from hypertension and who had suffered a stroke as cases, as well as 44 patients with hypertension and without stroke as controls. Cases and controls were conveniently selected at the outpatient clinic of Badung District Hospital. Data on self-management of diet, physical activity, stress mitigation efforts, alcohol consumption, and medication adherence were collected using self administered questionnaire. Data on the diagnosis of hypertension, stroke and history of comorbidities were obtained from the patient's medical records. Multivariate analysis using logistic regression was employed to assess the association between hypertension self-management with the incidence of stroke in patients with hypertension.

Results: Characteristics of cases and controls did not differ in education, marital and socioeconomic status, but differed in age and employment. Multivariate analysis showed that there were three components of hypertension self-management associated with the incidence of stroke, namely poor adherence to medication $(A O R=7.28$; $95 \% \mathrm{Cl}: 2.19-24.17)$, poor self-management of stress ( $A O R=5.45$; 95\% Cl: 1.56-18.99), and poor management of self-regulated diet $(A O R=5.28 ; 95 \% C l: 1.31-21.32)$.

Conclusion: Medication adherence, diet and stress management are the three main components of self-management that are associated with stroke events among hypertension patients. Efforts to increase medication adherence, diet and stress management should be enhanced.

Keywords: self management, medication adherence, diet, hypertension, stroke

Cite This Article: Sutini, N.K., Septarini, N.W., Wirawan, I.M.A., Sawitri, A.A.S. 2018. The association between hypertension self-management and stroke event in male patients at the Badung District Hospital, Bali. Public Health and Preventive Medicine Archive 6(2): 82-87. D01:10.15562/phpma. v6i2.14

${ }^{1}$ Institute of Health Sciences Bali (STIKES Bali), ${ }^{2}$ Department of Public Health and Preventive Medicine, Faculty of Medicine, Udayana University

${ }^{*}$ Correspondence to: Ni Kadek Sutini, Institute of Health Sciences Bali (STIKES Bali) kadek.sutini@yahoo.com

\section{INTRODUCTION}

Stroke is one of the major health problems in Indonesia. ${ }^{1}$ The prevalence of stroke in Indonesia is reported to have increased from 8.3 per 1,000 population in $2007^{2}$ to 12.1 per 1,000 population by $2013 .^{1}$ Although the Province of Bali occupies the $16^{\text {th }}$ position in the case of stroke reported in Indonesia, ${ }^{1}$ the prevalence of stroke in Bali Province was also reported to have increased from 4.4 per 1,000 population in $2007^{2}$ to 5.3 per 1,000 population by 2013. ${ }^{1}$ Globally, hypertension has been identified as a major risk factor for stroke, ${ }^{3}$ but undiagnosed and uncontrolled hypertension were also reported as one of the risk factors of stroke., The Indonesia Basic Health Research (Riskesdas) reported that hypertension prevalence in Indonesia had an increase from $7.6 \%$ in $2007^{2}$ to $9.5 \%$ in 2013. ${ }^{1}$ WHO reported an increased prevalence of hypertension in Indonesia even higher, that is $21.2 \%$ in 2010 to $23.3 \%$ in 2014 . $^{4}$ Similar trend was also reported in Bali Province. ${ }^{6}$
Despite the efforts of managing hypertension with pharmacological and nonpharmacological therapies, stroke and death from stroke continue to be a major problem. ${ }^{3,4}$ Understanding the appropriate strategy to control blood pressure remains a worldwide concern. ${ }^{3,7,8}$ World Health Organization (WHO) stated that self-management for hypertensive patients is an important component for controlling blood pressure. ${ }^{4}$ Self-management hypertension includes six self-care behaviors of dietary adherence, physical activity, stress control, limiting alcohol consumption, smoking cessation and medication adherence. ${ }^{4}$ Two studies in Africa ${ }^{9}$ and China ${ }^{10}$ reported that self-management in hypertensive patients remains low, especially the low-salt diet, ${ }^{9}$ physical activity and medication adherence. $^{10}$

Result of analysis of secondary data within the Indonesia Family Life Survey-4 reported 91\% of hypertension cases are 40 years and above, live with 
uncontrolled hypertension, ${ }^{11}$ and have a high risk of suffering a stroke. Published study on the role of self-management of hypertension to stroke has never been carried out in Indonesia. Other study into self-management has been more descriptive, such as that conducted in Mojokerto, East Java ${ }^{12}$ therefore, in order to fill this research gap, it is important to assess hypertension self-management association with the incidence of stroke.

The 2013 Bali Province Basic Health Research (Riskesdas) shows that Badung District is ranked third of nine districts/cities in the prevalence of hypertension. ${ }^{13}$ Badung district has one general hospital (Badung District Hospital) as the main public hospital. Data from this public hospital showed that in 2016 stroke was ranked first of 10 major diseases reported in the neurology outpatient clinic, while hypertension was ranked second after diabetes mellitus in the internal medicine outpatient clinic. Initial observations showed that one of the management mechanisms of hypertension in the Badung District Hospital is the provision of education to the patient about selfmanagement of hypertension. Nevertheless, until now there is no standardized guidelines in hospitals related to self-management of hypertension. This study aims to determine the association of

Table 1 Characteristics of cases and controls

\begin{tabular}{|c|c|c|c|c|c|}
\hline \multirow[b]{2}{*}{ Characteristics } & \multicolumn{2}{|c|}{ Cases } & \multicolumn{2}{|c|}{ Controls } & \multirow[b]{2}{*}{$\mathbf{p}$} \\
\hline & $\mathbf{n}$ & $\%$ & $\mathbf{n}$ & $\%$ & \\
\hline \multicolumn{6}{|l|}{ Age } \\
\hline 45-59 years & 20 & 45.5 & 9 & 20.5 & 0.01 \\
\hline$\geq 60$ years & 24 & 54.5 & 35 & 79.5 & \\
\hline \multicolumn{6}{|l|}{ Education } \\
\hline $\begin{array}{l}\text { Low (no schooling, elementary and } \\
\text { junior high) }\end{array}$ & 20 & 45.5 & 22 & 50.0 & 0.67 \\
\hline High (senior high and tertiary) & 24 & 54.5 & 22 & 50.0 & \\
\hline \multicolumn{6}{|l|}{ Marital status ${ }^{\star}$} \\
\hline Not married & 3 & 6.8 & 1 & 2.3 & 0.62 \\
\hline Married & 41 & 93.2 & 43 & 97.7 & \\
\hline \multicolumn{6}{|l|}{ Employment status } \\
\hline Employed & 38 & 86.4 & 26 & 59.1 & $<0.01$ \\
\hline Unemployed & 6 & 13.6 & 18 & 40.9 & \\
\hline \multicolumn{6}{|l|}{ Socioeconomic status } \\
\hline $\begin{array}{l}\text { Low/middle class }(\leq \text { minimum } \\
\text { wages=IDR } 2,100,000)\end{array}$ & 17 & 38.6 & 22 & 50.0 & 0.28 \\
\hline $\begin{array}{l}\text { Middle class and up }(>\text { minimum } \\
\text { wages=IDR } 2,100,000)\end{array}$ & 27 & 61.4 & 22 & 50.0 & \\
\hline Total & 44 & 100.0 & 44 & 100.0 & \\
\hline
\end{tabular}

*Analyzed with Fischer's exact test hypertension self-management with the incidence of stroke in patients with hypertension.

\section{METHODS}

A case-control study was employed with the case and control ratio of 1:1. The number of cases was 44 hypertensive patients diagnosed with stroke $\leq 1$ year by a neurologist based on anamnesis, neurologic examination and head CT scanning recorded in the neurological outpatient clinic record in Badung District Hospital. The controls were 44 hypertensive patients without stroke availabe on the outpatient clinic records of internal medicine at the same hospital. The number of samples (88 subjects) was determined with significance level of 0.05 , power of $80 \%$, proportion of low physical activity in the population of $26 \%$ and anticipated OR of 2.5. ${ }^{1}$ Cases and controls were conveniently selected, in which case patients presented at two-fold visits with a case-appropriate diagnosis in the neurological outpatient clinic, while controls were taken with the patient at each visit of multiple of 3 with appropriate diagnosis in the outpatient clinic of internal medicine.

Data were collected from March to May 2017. Data on respondents' characteristics and selfmanagement of hypertension were collected using self administered questionnaire. The questionnaire used is a modification of the hypertension selfmanagement standard questionnaire developed by Tsubota and Inagaki in Japan, ${ }^{14}$ and has been tested for its validity and reliability. Each component of self-management hypertension is categorized into two that is 'good' and 'poor'. Good category if the answer is equal to or more than $75 \%$ of the total maximum score of the component, while the poor category is less than $75 \%$ of the total maximum score. Data were analysed using STATA SE 12.1. The association between hypertension self-management and the incidence of stroke in hypertensive patients was analyzed using multiple logistic regression with backward stepwise (LR) method. This study has been approved by the Human Research Ethic Committee Faculty of Medicine Udayana University/Sanglah General Hospital Denpasar on March 24, 2017.

\section{RESULTS}

Table 1 shows the demographic characteristics of cases and controls, which indicates that there is no significant difference between cases and controls with regards to education, marital and socioeconomic status. However, there was a significant difference in age and employment status. 
Table 2 Crude OR and adjusted OR of stroke risk factors

\begin{tabular}{|c|c|c|c|c|c|c|c|c|}
\hline \multirow[b]{2}{*}{ Variable } & \multicolumn{2}{|c|}{ Cases } & \multicolumn{2}{|c|}{ Controls } & \multirow{2}{*}{$\begin{array}{l}\text { Crude } \\
\text { OR }\end{array}$} & \multirow[b]{2}{*}{$\mathbf{p}$} & \multirow{2}{*}{$\begin{array}{l}\text { Adjusted } \\
\text { OR }\end{array}$} & \multirow[b]{2}{*}{$95 \% \mathrm{Cl}$} \\
\hline & $\mathbf{n}$ & $\%$ & $\mathbf{n}$ & $\%$ & & & & \\
\hline \multicolumn{9}{|l|}{ Age } \\
\hline $45-59$ years & 20 & 45.6 & 9 & 20.6 & 0.31 & 0.01 & & \\
\hline$\geq 60$ years & 24 & 4.5 & 35 & 9.5 & & & & \\
\hline \multicolumn{9}{|c|}{ Employment status } \\
\hline Employed & 38 & 59.4 & 26 & 40.6 & 4.39 & $<0.01$ & & \\
\hline Unemployed & 6 & 25.0 & 18 & 75 & & & & \\
\hline \multicolumn{9}{|c|}{ Family history of stroke } \\
\hline Yes & 14 & 31.8 & 6 & 13.6 & 2.95 & 0.04 & & \\
\hline No & 30 & 68.2 & 38 & 86.4 & & & & \\
\hline \multicolumn{9}{|c|}{ Diabetes mellitus } \\
\hline Yes & 12 & 27.3 & 20 & 45.5 & 0.45 & 0.08 & & \\
\hline No & 32 & 72.7 & 24 & 54.5 & & & & \\
\hline \multicolumn{9}{|l|}{ Dyslipidemia } \\
\hline Yes & 11 & 25.0 & 6 & 13.6 & 2.11 & 0.18 & & \\
\hline No & 33 & 75.0 & 38 & 86.4 & & & & \\
\hline \multicolumn{9}{|l|}{ Heart disease } \\
\hline Yes & 7 & 15.9 & 5 & 11.4 & 1.47 & 0.53 & & \\
\hline No & 37 & 84.1 & 39 & 88.6 & & & & \\
\hline \multicolumn{9}{|c|}{ Self-management of diet } \\
\hline Poor & 39 & 88.6 & 25 & 56.8 & 5.92 & $<0.01$ & 5.28 & $1.31-21.32$ \\
\hline Good & 5 & 11.4 & 19 & 43.2 & & & & \\
\hline \multicolumn{9}{|c|}{ Self-management of exercise } \\
\hline Poor & 25 & 56.8 & 15 & 34.1 & 2.54 & 0.03 & & \\
\hline Good & 19 & 40.9 & 29 & 65.9 & & & & \\
\hline \multicolumn{9}{|c|}{ Self-management of stress } \\
\hline Poor & 26 & 59.1 & 7 & 15.9 & 7.63 & 0.00 & 5.45 & $1.56-18.99$ \\
\hline Good & 18 & 40.9 & 37 & 84.1 & & & & \\
\hline \multicolumn{9}{|c|}{$\begin{array}{l}\text { Self-management of alcohol } \\
\text { use }^{\star}\end{array}$} \\
\hline Poor & 5 & 11.4 & 1 & 2.3 & 5.51 & 0.20 & & \\
\hline Good & 39 & 88.6 & 43 & 97.7 & & & & \\
\hline \multicolumn{9}{|c|}{ Self-management of smoking } \\
\hline Poor & 18 & 40.9 & 7 & 15.9 & 3.65 & $<0.01$ & & \\
\hline Good & 26 & 59.1 & 37 & 84.1 & & & & \\
\hline \multicolumn{9}{|c|}{ Medication adherence } \\
\hline Poor & 33 & 75.0 & 10 & 22.7 & 10.20 & 0.00 & 7.28 & $2.19-24.17$ \\
\hline Good & 11 & 25.0 & 34 & 77.3 & & & & \\
\hline Total & 44 & 100.0 & 44 & 100.0 & & & & \\
\hline
\end{tabular}

"Analysed with the Fisher's exact test

Table 2 shows the crude OR of demographic characteristics, comorbidities and six selfmanagement components. It was found that comorbidities, family history, self management of diet, physical activity, stress, smoking habit, and adherence of medication were associated with stroke. While the self management of alcohol use was found not significantly associated with stroke. Eleven variables with $p$ value $<0.25$ were included in the multivariate analysis. 
Multivariate analysis shows that the variables associated with stroke event in hypertensive patients were poor medication adherence $(\mathrm{AOR}=7.28$, 95\%CI: 2.19-24.17), poor self-management of stress $(\mathrm{AOR}=5.45 ; 95 \% \mathrm{CI}: 1.56-18.99)$ and poor management of self-regulated diet $(\mathrm{AOR}=5.28$; 95\%CI: 1.31-21.32).

\section{DISCUSSION}

This study shows three components of selfmanagement of hypertension significantly associated with stroke events, namely medication adherence, self-management of stress and selfmanagement of diet.

Descriptive analysis of medication adherence component showed that poor medication adherence among cases was higher compared to controls regarding forgetting to take medication, not taking medication when blood pressure was normal or taking medication without complying with instructions on the number and dose of the drug. This finding is consistent with the 2013 Indonesia Basic Health Research (Riskesdas) which stated that only $9.5 \%$ of patients on hypertensive treatment were adhered. ${ }^{1}$ Non-adherence to antihypertensive drugs is not only reported in Indonesia, but also in Asian populations. ${ }^{15}$ A retrospective cohort study in the United States found that medication adherence in hypertensive patients may reduce the risk of stroke. ${ }^{16}$ Population-based studies in Europe also reported that in 2 and 10 years of follow-up after the initiation of anti-hypertensive drugs, patients with poor adherence were at increased risk for stroke and stroke-related deaths. ${ }^{17}$

The poor self-management of stress in this study focuses on work management items, where cases tend not to be able to manage time to rest and work as compared to the controls. This may be associated with the high burden of employment that increases the stress response and affects the cardiovascular system..$^{18}$ The findings of this study are similar with several other studies suggesting that stress is a risk factor for stroke. A prospective cohort study in Japan $^{19}$ and a meta-analysis in Europe ${ }^{20}$ suggested that job stress increases the risk of stroke. Similar findings were reported in other meta-analysis studies, suggesting that stress increases the risk of stroke. $^{21,22}$

The association between poor self-management of diet with stroke incidence in patients with hypertension may be contributed by dietary behavior of salt and fat diet, where cases tend to more consume fatty and salty foods compared to controls. A cohort study in Japan and in the United States stated that excessive salt consumption ${ }^{23}$ and fatty foods ${ }^{24}$ places on at risk of stroke. Furthermore, a low-salt diet is reported to be able to lower blood pressure by $2-8 \mathrm{mmHg}$, while low-fat diet is able to decrease blood pressure of $8-14 \mathrm{mmHg}$, thus reducing the risk of stroke. ${ }^{7}$

In our study, self-management of physical activity is not associated with stroke incidence in hypertensive patients. It shows that the physical activity performed by cases and controls is relatively similar and good enough, for example in terms of seeking information on sports, regular aerobic exercise, and walking. The results of this study are similar with a baseline subset data analysis study conducted in Bogor, West Java which found that the lack of physical activity was not a risk factor for stroke compared with those with sufficient physical activity. ${ }^{25}$ In contrast, our results were not consistent with the results of data analysis on The 2013 Indonesia Basic Health Research (Riskesdas) ${ }^{26}$ which stated that respondents with less physical activity showed a higher prevalence of stroke compared with those who did enough physical activity. In addition, study in India also stated that physical activity is a risk factor for stroke. ${ }^{27}$

In the present study, self-management of smoking is not associated with the incidence of stroke in patients with hypertension. This finding is consistent with a case-control study in Balangan, Kalimantan Selatan, which stated that smoking is not related to stroke. ${ }^{28}$ Our further analysis shows that smoking in cases and controls appear no different in an effort to reduce the number of cigarettes consumed daily and the ability to choose alternatives other healthy activities when wanting to smoke. However, different results were found in Taiwan suggesting that smoking is a risk factor for stroke. ${ }^{29}$ A study in The United States found that smoking every day increases 2-4 times the risk of suffering stroke compared with those who never smoked. $^{30}$

This current study shows that the poor management of alcohol use is not associated with stroke incidence in patients with hypertension. Our analysis found that hypertensive patients in both case and control groups tend to drink mild alcohol ( $\leq 400 \mathrm{ml}$ ) daily. The results of this study are similar with a study conducted in Manado, which found that mild alcohol consumption is protective against stroke events. ${ }^{31}$ In contrast, a meta-analysis in Australia reported that respondents who consumed alcohol $\pm 200 \mathrm{ml}-400 \mathrm{ml}$ showed a low adjusted RR for a stroke while the $\pm 1000 \mathrm{ml}$ alcohol use showed a higher adjusted RR for stroke. ${ }^{32}$ Another meta-analysis also reported that alcohol consumed $>1000 \mathrm{ml}$ is a risk factor for stroke in Asian populations. ${ }^{33}$

As mentioned earlier, the provision of information for the reduction of risk behaviors in 
hospitalized hypertensive patients in the Badung Regional Hopital has been performed, but the given components have not been standardized on six self-management components of hypertension. The results of this study indicate the need for health workers to provide health education to patients with hypertension, especially in maintaining adherence to medication, diet and good self-management of stress to prevent stroke. To improve the benefits to the patient, the provision of such information needs to be standardised for all health workers in the hospital.

The limitation of this study is the possibility of biased recall on self-management assessment of hypertension and respondents' tendency to provide good answers to hypertensive selfmanagement statements, although the researcher has made control efforts by making additional statements on the questionnaire related to selfmanagement. Although this study shows the three components of self-management are significantly related to the incidence of stroke, this study has not yet answered whether performing these three self-management components is the minimum standard that should be done by hypertensive patients to avoid stroke.

\section{CONCLUSION}

Failure to adhere to taking hypertension medications, poor self-management of stress, along with poor self-management of bad diets play a role in the incidence of stroke in people with hypertension. Efforts to improve hypertension selfmanagement education are required.

\section{ACKNOWLEDGEMENT}

We would like to thank the Director of Badung Regional Hospital, the Head of the Outpatient Clinic of Neurology and the Outpatient Clinic of the Internal Medicine who had supported the study implementation and all respondents who participated in this study.

\section{REFERENCES}

1. Ministry of Health of Indonesia. Riset Kesehatan Dasar 2013 [The 2013 Indonesia Basic Health Research]. 2014.

2. Ministry of Health of Indonesia. Riset Kesehatan Dasar 2007 [The 2007 Indonesia Basic Health Research]. 2008.

3. World Health Organization. A global brief on hypertension: Silent killer, global public health crisis. Geneva. 2013.

4. World Health Organization. Global status report on noncommunicable diseases. Geneva. 2014.

5. Klungel OH, Kaplan RC, Heckbert SR, Smith NL, Lemaitre RN, Longstreth WT Jr, et al. Control of blood pressure and risk of stroke among pharmacologically treated hypertensive patients. Stroke. 2000. 31(2): 420-4.
6. Bali Provincial Health Office. Profil Kesehatan Provinsi Bali tahun 2014 [The 2014 Bali Province Health Profile]. 2015.

7. Chobanian AV, Bakris GL, Black HR, Cushman WC, Green LA, Izzo JL Jr, et al. The seventh report of the Joint National Committee on prevention, detection, evaluation, and treatment of high blood pressure. Hypertension. 2003. 42(6): 1206-52.

8. Ministry of Health of Indonesia. Infodatin pusat data dan informasi Kementerian Kesehatan RI: Hipertensi [Centre of data and information Indonesia Ministry of Health: Hypertension]. 2014.

9. Warren-Findlow J, Seymour RB. Prevalence rates of hypertension self-care activities among African Americans. Journal of the National Medical Association. 2011. 103: 503-512.

10. $\mathrm{Hu} \mathrm{H}, \mathrm{Li} \mathrm{G}$, Arao T. Prevalence rates of self-care behaviors and related factors in a rural hypertension population : A questionnaire survey. International Journal of Hypertension. 2013. 2013; 526949.

11. Hussain MA, Mamun AA, Reid C, Huxley RR. Prevalence, awareness, treatment and control of hypertension in Indonesian adults aged $>40$ years: findings from the Indonesia Family Life Survey (IFLS). PLoS One. 2016; 11(8): 1-16.

12. Tamora VY. Self care penderita hipertensi di Desa Pekuwon, Kecamatan Bangsal, Kabupaten Mojokerto [Self care among hypertensive patients in Pekuwon Village, Bangsal Subdistrict, Mojokerto District]. 2014. Available at: http://www.repository.poltekkesmajapahit.ac.id/index. php/PUB-KEP/article/view /51/0

13. Pranata S, Fauziah Y, Budisuari MA, Kusrini I. Riset Kesehatan Dasar dalam Angka: Provinsi Bali 2013 [The 2013 Basic Health Research in Numbers: Bali Province]. Ministry of Health of Indonesia. 2013.

14. Tsubota K, Michiko I. Development of a self-management scale for the evaluation of behavior in daily life in patients with hypertension: an investigation of reliability and validity. Journal of the Tsuruma Health Science Society Kanazawa University. 2012; 36(1): 1-10.

15. Costello Medical Singapore Pte Ltd. Presented at the International Society for Pharmacoeconomics and Outcomes Research. Singapore. September 3-6. 2016.

16. Bailey JE, Wan JY, Tang J, Ghani MA, Cushman WC. Antihypertensive medication adherence, ambulatory visits, and risk of stroke and death. Journal of General Internal Medicine. 2010; 25(6): 495-503.

17. Herttua K, Tabák AG, Martikainen P, Vahtera J, Kivimäki M. Adherence to antihypertensive therapy prior to the first presentation of stroke in hypertensive adults: Population-based study. European Heart Journal. 2013; 34(38): 2933-2939.

18. Chandola $\mathrm{T}$, Britton A, Brunner E, Hemingway $\mathrm{H}$, Malik M, Kumari $M$, et al. Work stress and coronary heart disease: what are the mechanisms?. European Heart Journal. 2008; 29(5): 640-648.

19. Tsutsumi A, Kayaba K, Kario K, Ishikawa S. Prospective study on occupational stress and risk of stroke. Archive of Internal Medicine. 2009; 169(1): 56 - 61.

20. Fransson EI, Nyberg ST, Heikkilä K, Alfredsson L, Bjorner JB, Borritz M, et al. Job strain and the risk of stroke an individual-participant data meta-analysis. Stroke; 46(2): 557-559.

21. Dong JY, Zhang YH, Tong J, Qin LQ. Depression and risk of stroke: A meta-analysis of prospective studies. Stroke 2012; 43: 32-37.

22. Booth J, Connelly L, Lawrence M, Chalmers C, Joice S, Becker C, et al. Evidence of perceived psychosocial stress as a risk factor for stroke in adults: a meta-analysis. $B M C$ Neurology. 2015; 15: 233.

23. Okayama A, Okuda N, Miura K, Okamura T, Hayakawa T, AkasakaH, et al. Dietary sodium-to-potassium ratio as a risk factor for stroke, cardiovascular disease and all-cause mortality in Japan: the NIPPON DATA80 cohort study. BMJ Open. 2016; 6(7). 
24. Judd SE, Gutiérrez OM, Newby PK, Howard G, Howard VJ, Locher JL, et al. Dietary patterns are associated with incident stroke and contribute to excess risk of stroke in black Americans. Stroke 2013; 44(12): 3305-3311.

25. Riyadina W, Rahajeng E. Determinan Penyakit Stroke [Determinants of stroke]. Kesmas National Public Health Journal. 2013; 7(7): 324-330.

26. Ghani L, Mihardja LK, Delima. Faktor risiko dominan penderita stroke di Indonesia [Dominant risk factors of stroke in Indonesia]. Buletin Penelitian Kesehatan. 2016; 44(1): 49-58.

27. Mohan A, Praveen PS, Nujum ZT. Risk factor profile of stroke patients with special focus on determinants of severity. Journal of Comprehensive Health. 2016; 4(1): 57-71.

28. Solehin MM, Hamzah, Nurhikmah. Analysis of risk factors of stroke incidence in RSUD Balangan and Puskesmas Balangan 2016. Caring. 2016; 2(2): 73-87.

29. Hsieh FI, Chiou HY. Stroke: morbidity, risk factors, and care in Taiwan. Journal of Stroke. 2014; 16(2): 59-64.

30. Shah RS, Cole JW. Smoking and stroke: the more you smoke the more you stroke. Expert Review of Cardiovascular Therapy. 2010; 8(7): 917-32.
31. Patricia H, Kembuan MAHN, Tumboimbela MJ. Karakteristik penderita stroke iskemik yang di rawat inap di RSUP Prof. Dr. R.D. Kandou Manado tahun 2012-2013 [Characteristics of ischemic stroke patients in Prof. Dr. R.D Kandou Hospital Manado 2012-2013]. Jurnal E-Clinic 2015; 3(1): 445-451.

32. Hankey GJ. Potential new risk factors for ischemic stroke: What is their potential? Stroke 2006; 37(8): 2181-2188.

33. Chen X, Zhou L, Zhang Y, Yi D, Liu L, Rao W, et al. Risk factors of stroke in Western and Asian Countries: A systematic review and meta-analysis of prospective cohort studies. BMC Public Health. 2014; 14: 776.

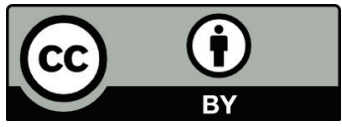

This work is licensed under a Creative Commons Attribution 